Вінтоняк В. кандидат психологічних наук, Національний університет оборони Украӥни імені Івана Черняховського ORCID ID 0000-0002-3878-1848

\title{
ПСИХОЛОГІЯ ВИРІШЕННЯ ПРОБЛЕМИ ВІЙСЬКОВИМ ЛІДЕРОМ
}

Здійснено спробу психологічного осмислення проблеми лідерства у військово-соціальному управлінні. Окресленні основні теорії лідерства. 3'ясовано поняття “проблема”, розкрито типологію проблем у військово-професійній діяльності, наведені стратегії вирішення проблем які стоять перед військовим управлінщем. Розкрито сутність застосування типологї проблем до завдань у галузі військової практики.

Ключові слова: лідер; проблема; управління; ефективність; збройні сили.

Постановка проблеми. На сьогодні членство в НАТО $є$ однією 3 головних стратегічних цілей України, а європейські принципи - основним оріснтиром розвитку держави. Розвиток сучасної української армії не може грунтуватися на радянських принципах управління, оскільки сучасність вимагає нових підходів до управління у військовій сфері, побудови такої взаємодії між військовослужбовцями яка буде грунтуватися на повазі, авторитеті, відповідальності та інших цінностях українського війська.

Водночас, однією із найважливіших умов розвитку сучасних Збройних Сил України $є$ розвиток лідерства на всіх рівнях управління. I одним із критерій ефективності управлінської діяльності військового лідера $є$ уміння правильно та своєчасно розв'язувати завдання та проблеми які постають перед ним в руслі професійної діяльності.

Аналіз останніх публікацій. Значний теоретико-методологічний i практичний внесок у дослідження проблеми лідерства зробили такі зарубіжні дослідники як, Д. Гоулман, Д. Карузо, Дж. Мейер, К. Левін, Д. Макгрегор, Е. Маккі, Є. Дирінг, Г. Мінс, Дж. Френч, Е. Флейшман. Теорії лідерства досліджували: “теорія рис" М. Вебер, Е. Кац, Е. Богардус, Л. Бернард, В. Бинхам, К. Берд, “ситуаційна теорія лідерства" (Т. Хейлін, Ц. Джиб, Ф. Фідлер та ін.), “інтеракціоніська теорія" (К. Гіб, К. Кліфорд та ін.), двомірна модель лідерства Р.Блейка і Дж. Моутона., мотиваційна теорія М. Еванса, гуманістичний підхід (Р. Лайкерт та ін.), атрибутивні теорії лідерства (Р. Лорд, Дж. Фотіс та ін.), теорія нормативних рішень (В. Врум та Ф. Йєттон), трансформаційне лідерство Б. Аволіо, Б. Бас) та ін. Серед вітчизняних науковців лідерство досліджували: В. Є. Михайличенко, О.Г. Романовський, .А. Пашко, Л.Карамушка, А. Кравченко, Р. Кричевський, Б.Паригін, А.Петровський, І.Столяр, Л.Уманський та iн. Питаннями лідерства займалися i військові дослідники, такі як В. Осьодло, О. Хміляр, О. Бойко.

Не зважаючи на те, що теоретичні засади лідерства неодноразово були предметом дослідження у наукових працях вітчизняних i зарубіжних дослідників, системних наукових досліджень психології вирішення проблеми військовим лідером як феномену управління не здійснювалося.

Мета статті: аналіз психологічних особливостей вирішення проблеми військовим лідером в управлінській діяльності.

Виклад основного матеріалу. Однією 3 найактуальніших проблем сьогодення в сучасній українській армії стала тема лідерства, як необхідного атрибуту управлінської діяльності офіцера.

Звичайно, справжнім лідером не кожен може стати. Сучасне розуміння “справжнього лідера" дещо відрізняється від тих уявлень, які були сформовані в Збройних Силах України за часів 


\section{Питання психології}

Радянського Союзу та перебудови. На всім відомі тези “лідером потрібно народитися", “обов'язкова наявність лідерських якостей”, “харизма” прийшли нові твердження, такі, наприклад, як ефективність лідера, вміння вирішувати проблеми, стратегічне бачення власної діяльності та розвитку організації.

Історія не знає більш харизматичних лідерів ніж “велика трійка" XX століття: Сталін, Гітлер, Мао - деспоти, які принесли людям більше страждань ніж людство пережило за всю свою історію. Ефективне лідерство не залежить від харизми. Джордж Маршалл, Гаррі Трумен, Авраам Лінкольн, Вінстон Черчилль не були харизматичними людьми, але були надзвичайно ефективними керівниками. Більш того, харизма може знищити лідера, оскільки вона заважає бути гнучким, заставляє їх вірити у власну неперевершеність, робить ïx не здатними до змін.

Сутність сучасного лідерства полягає не стільки в своєчасній реакції на наявні проблеми, а на передбачення проблем завтрашнього дня. Хто працює сьогодні над проблемами завтрашнього дня, таким чином готує себе і свою організацію до нових завдань. Той же, хто відкладає вирішення цих питань на потім, залишиться позаду i, можливо, ніколи не зможе надолужити згаяне [3].

Вміння бути лідером - це, перш за все, праця. Фундамент ефективного лідерства закладається на етапі, коли керівник продумує, визначає та чітко формує головну місію своєї організації. Лідер визначає цілі та пріоритети своєї організації; він також встановлює та підтримує певні стандарти. Ефективні лідери чітко розуміють межі своїх можливостей, бачать різницю між можливим i бажаним. Лідер повинен сприймати своє лідерство як відповідальну місію, а не сприймати його як звання, яке забезпечить йому певні привілеї та владу.

3 приводу лідерства у військовій сфері, то на сьогоднішній день це стало невід'ємною частиною основних вимог до керівника будь-якого рівня управління.
Військовий лідер повинен приймати ефективні рішення та розв'язувати проблеми, які стоять перед ним. Військові керівники, які вміють приймати ефективні рішення, не приймають багато рішень, але вони приймають рішення, від яких багато що залежить, a насамперед, життя людини. Крім того, вони знають коли рішення необхідно i, в таких випадках, не зволікають. Такі лідери знають, що найважливіша i найскладніша частина цього процесу - не саме прийняття рішення, а впевненість у тому, що рішення приймається щодо тієї проблеми, яка дійсно важлива $[6,7]$.

Військові лідери, які вміють приймати ефективні рішення, вміють визначати проблему. Вони запитують себе: "Яким має бути рішення щоб воно підходило для даної проблеми?”. В цьому випадку, рішення можна вважати прийнятим тільки тоді, коли воно включає в себе план реалізації і критерії та показники ефективності. Без цього це зовсім не рішення, а лише хороша ідея. Крім того, відомо, що рішення означає заклик до дії. I практично завжди доводиться діяти разом 3 іншими людьми, у яких повинні бути відповідні здібності, розуміння, знання, спільні цінності.

В чому ж полягає сутність поняття "проблема"? Під "проблемою" розуміється:

- певна

невідповідність фактичного стану об'єкта чи процесу яким керують, бажаному або заданому (запланованому); зв'язок між двома явищами, що містить протиріччя і носить деструктивний характер по відношенню до цілей організації;

- ситуація, коли не досягнута ціль;

- ситуація, створена внутрішніми чи зовнішніми подіями в яких і містяться можливі шляхи вирішення;

- потенційна можливість (в цьому випадку, проблему усвідомлюють тоді коли із потенційної можливості можна отримати певну вигоду).

Завжди потрібно пам'ятати, що одна 3 найскладніших проблем - це визначення проблеми. Знати, в чому різниця між поточним і бажаним станом, 


\section{Питання психології}

де дійсно, приховано проблеми; як знайти ïx у складнощах причинно-наслідкових зв'язків, наскільки є складною проблема визначення заходів, які б ефективно нівелювали розрив між існуючим i бажаним станом.

Перед керівниками можуть виникнути проблеми чотирьох видів.

1. Загальні проблеми, характерні для всієї організації або галузі.

2. Загальні проблеми, характерні для окремої організації, але не відомі для галузі в цілому.

3. Дійсно унікальні проблеми.

4. Проблеми, які здаються унікальними, але насправді являються першою ознакою нової загальної проблеми [2].

Для всіх проблем, за винятком дійсно унікальних, потрібні спільні рішення. Загальні проблеми можна вирішувати стандартними правилами та методами. Як тільки буде сформульований правильний принцип, 3 однієї і тієї ж загальної проблемою в будь-яких іiї проявах можна буде впоратися за допомогою цього стандартного методу. Все, що залишиться зробити керівнику, - це пристосувати принцип до конкретної ситуації.

Однак для унікальних проблем потрібні унікальні рішення, до прийняття яких слід підходити індивідуально. Керівник не може створити єдиний алгоритм дій чи певні правила розв'язання непередбачуваних, виняткових проблем. I дійсно, унікальні проблеми трапляються вкрай рідко.

Практично будь-яку проблему, 3 якою стикається організація, хтось колись вже вирішував. Отже, людина, що приймає рішення, повинна уважно вивчити проблему і визначити, до якого типу вона відноситься - дійсно унікальних або загальних. Вирішити більшість проблем можна за допомогою стандартного правила або принципу.

Наступний ключовий елемент процесу - визначення проблеми. Більшість iз нас ніколи над цим не замислювалися. Хіба проблеми не очевидні? Цілком ймовірно, це найважливіший елемент всього процесу прийняття ефективного вирішення, - i незважаючи на це, керівники практично ніколи не звертають на нього уваги. Вони намагаються лікувати симптоми, а не саму хворобу, якщо говорити мовою медицини.

Майже не замислюючись, можна погодитися, що проблема насправді виявляється не такою, як здається на перший погляд. Однак, ніщо не може бути небезпечніше, ніж правильне рішення неправильної проблеми $[1,2]$. Як правило, помилкове рішення правильної проблеми можна виправити i скорегувати. Якщо результати не співпадають 3 вашими очікуваннями, ви дуже скоро про це дізнаєтеся і зрозумієте, що рішення було неправильним. Але, правильне рішення неправильної проблеми виправити дуже складно, а то й взагалі неможливо, оскільки його вкрай складно виявити. Досвідчені лідери навчилися відштовхуватися від припущення про те, що проблема насправді буде зовсім не такою, якою здається на перший погляд. Після цього вони роблять все, щоб усвідомити справжню проблему.

Як лідери, які вміють приймати ефективні рішення, визначають правильну проблему? Вони задають собі наступні запитання:

- про що взагалі йде мова?

- що характерно для даної ситуації?

- що головне в цій ситуації?

Подібні запитання далеко не нові, але відіграють дуже важливу роль при визначенні проблеми. Щоб переконатися, що ви вирішуєте правильну проблему, ситуацію потрібно розглянути 3 усіх можливих точок зору. Єдиний спосіб переконатися в тому, що проблема була визначена не правильно, - оцінити іiі в порівнянні $з$ фактами. Якщо визначення проблеми не пояснює і не охоплює всі наявні факти, воно не може вважатися досконалим, тому, швидше за все, $\epsilon$ помилковим.

Також, будь-яку проблему можна розглядати у трьох площинах: об'єктивній, проблему відносин $i$ економічній [4].

Проблема об'єктивна щоразу, коли перед суб'єктом, постає завдання яке 


\section{Питання психології}

важко вирішити, і він не може ухилитися від його розв'язати. Проблема об'єктивна ще в тому сенсі, що пересилює над суб'єктністю індивіда, над його можливостями, стандартами його типу особистості, розуму, організації. Так, наприклад, хвороба є об'єктивною проблемою, оскільки в цей момент об'єкт може завдати шкоди собистості. Сутність проблеми знищує суб'єкта i як прояв життя, і як діяльне начало. Наприклад, людина заразилася СПІДом, і тепер вірус вражає весь організм, чужа форма заселяє тіло, проблема об'єктивувалась на рівні керуючої зони, свідомості, тіла.

Для проблеми відносин характерне виникнення ускладнень, непорозумінь, інформаційних феноменів, імпульсивних дій і контактів. Це особливості способів прийому і передачі інформації суб'єктом. Існує щось, що порушує або відхиляє прямий контакт, відчужують індивіда від його робочого контексту, від значущих для нього в даному місці стандартів відносин (з друзями, партнерами, рідними, працівниками всередині якогось соціального образу).

Проблема стає економічною, коли ззовні приходить щось, що несе індивіду (чи організації яку він очолює) заробіток, або втрати. Це технічний аспект обробки даних існуючої кризи або пропозицій ринку. Проблема даного типу знаходиться поза об'єктивністю, яка може переважати над суб'єктом, поза оперативним пізнанням. Це всього на всього можливість, яка може бути для суб'єкта як ростом і розвитком, так і регресом, однак вона не спотворює його життя, особистість, відносини, не позбавляє його організацію якою він керує центрального положення, а його - поваги [4].

По суті, для вирішення проблем всіх типів існує одна і та ж технічна логіка. Логіка єдина, а методи які застосовуються і потреби залежать від типології проблеми (об’єктивна, відносин, економічна).

При вирішенні об'єктивної проблеми початковим критерієм аналізу є об'єкт, а не індивід. При аналізі слід відштовхуватися від сутності, модусу, складності об’єкта. При вирішенні об'єктивної проблеми людина повинна виходити з факту проблеми як такої, тобто аналізувати реальність i модуси проблеми, не думати про себе, а переміститися в об'єкт і зсередини об'єкта аналізувати ситуацію.

У випадку вирішення проблеми, типу відносин, необхідно проаналізувати подвійність відносин “я і інший”, сутність власної організації, узгодженість чи розбіжність у статусі в професійному середовищі, уточнити джерело, характер і силу помилки - це моя помилка чи помилка іншого боку?

При аналізі економічної проблеми слід розглядати лише можливості з3овні, іншими словами, не аналізувати себе, свою організацію, комунікацію, а те, чи зможе ця справа, річ, зустріч, новина увійти в моє поле діяльності. При позитивній відповіді слід уточнити алгоритм подальших дій. При негативному - не витрачати час і шукати нові можливості.

При вирішенні проблем будь-якого типу найважливіше - це точний підхід до аналізу, до вибору точки спостереження, точки опори в складній динаміці, що обертається можливістю або небезпекою, оскільки від цього залежить знаходження пропорції. Крім того, аналіз проблеми повинен бути технічним, без роздумів про справедливість або несправедливість того, що відбувається, оскільки, якщо ми починаємо оцінювати ситуацію 3 позицій “справедливо - несправедливо", то вже робимо помилку, йдемо від техніки, від пріоритету - знайти рішення, врівноважити всі функції і відносини.

При аналізі проблеми, по-перше, слід зайняти позицію нейтралітету. Суб'єкт повинен вийти за рамки взаємозв'язку “я як особистість - проблема”. Йому потрібно змінити позицію, переміститися в третю точку, звідки він ззовні зможе спостерігати за своєю поведінкою, за проблемою, тобто віддалитися і поглянути на неї без власного інтересу, ідеології, пристрасті, агресивності. Вирішення проблеми практично неможливо знайти в стані агресії, інфантилізму, ліні, надзацікавленності, самовпевненості. Для цього потрібна безпристрасна техніка. 


\section{Питання психології}

Суб'єкт $з$ неупередженістю повинен оцінювати, скільки солдатів знаходиться в його розпорядженні, а скільки виступає протии. Він повинен подивитися на ситуацію як на сукупність силових точок, які або взаємодіють один 3 одним, або вносять безлад, грають за або протии, поглянути на ситуацію як на уривки реальності, котрі у відповідності 3 векторною заданістю утворюють певну подію, яка залучає самого суб'єкта $[1,4]$.

По суті, для вирішення проблем всіх типів існує одна і та ж технічна логіка. Логіка єдина, а застосовувані методи i потреби залежать від типології проблеми. Підсумовуючи вищевикладений матеріал, можемо зробити висновок, що сучасному етапі функціонування збройних сил лідерство являється не просто ефективним регулятором управлінської діяльності, а складовою частиною самого процесу управління.

Перспективами подальших досліджень у цьому напрямі можуть бути проблеми впровадження та розвитку лідерства в діяльність Збройних Сил України.

\section{Список використаних джерел}

1. Дафт Р. Л. Менеджмент / Р.Л. Дафт ; пер. з англ. - СПб. : Пітер, 2012. - 863 с.

2. Друкер П., Ф. Макьярелло, А. Джозеф Менеджмент.: Пер. с англ. - М.: ООО “И.Д. Вильямс", 2010. - 704 с.

3. Друкер П.Ф. Менеджмент. Вызовы ХХІ века. - М.: “Манн, Иванов и_Фербер ”, 2012. - 256 c.

4. Менегетти А. Психология лидера / А. Менегетти / / Перевод с итальянского ННБФ “Онтопсихология".- М.: ННБФ "Онтопсихология", 2015. - 333 с.

5. Эффективный руководитель. - М.: Манн, Иванов и Фербер, 2012. - 240 с.

6. Army Leader Development Strategy [електронний ресурс]. - Режим доступу: http://data.cape.army.mil/web/character-development-project/repository/alds-2013.pdf.

7.NATO Code of Conduct [електронний pecypc]. - Режим доступу: https://www.nato.int/structur/recruit/info-doc/code-of-conduct.pdf.

\section{References}

1. Daft R.L. Menedzhment / R.L. Daft ; per. z anhl. - SPb. : Piter, 2012. -863 s.

2. Druker P., F. Makiarello, A. Dzhozef Menedzhment.: Per. s anhl. - M.: OOO "Y.D. Vyliams", 2010. - $704 \mathrm{~s}$.

3. Druker P.F. Menedzhment. Vиzovи XXI veka. - M.: «Mann, Yvanov y Ferber», 2012. - 256 c.

4. Menehetty A. Psykholohyia lydera / A. Menehetty / / Perevod s ytalianskoho NNBF "Ontopsykholohyia".- M.: NNBF "Ontopsykholohyia", 2015. - 333 s.

5. Эffektyvnыi rukovodytel. - M.: Mann, Yvanov y Ferber, 2012. - 240 c.

6. Army Leader Development Strategy [elektronnyi resurs]. - Rezhym dostupu: http://data.cape.army.mil/web/character-development-project/repository/alds-2013.pdf.

7.NATO Code of Conduct [elektronnyi resurs] - Rezhym dostupu: https://www.nato.int/structur/recruit/info-doc/code-of-conduct.pdf.

\section{Резюме}

Винтоняк В. кандидат психологических наук, НУОУ имени Ивана Черняховського

ORCID ID 0000-0002-3878-1848

\section{ПСИХОЛОГИЯ РЕШЕНИЯ ПРОБЛЕМЫ ВОЕННЫМ ЛИДЕРОМ}

Осуществлено попытку психологического осмысления проблемы лидерства в военносочиальном управлении. Определено основные теории лидерства. Проанализировано понятие "проблема", раскрыто типологию проблем в военно-профессиональной деятельности, приведены стратегии решения проблем, которые стоят перед военным управленщем. Раскрыта сущность применения типологии проблем с задачами в области военной практики.

Ключевые слова: лидер; проблема; управление; эффективность; вооруженные силь. 


\section{Питання психології}

\section{Summary}

Vintoniak $\boldsymbol{V}$. candidate of psychological sciences,

National Defence University of Ukraine

named after Ivan Chernyahovskyi

\section{PSYCHOLOGY OF PROBLEM SOLVING BY MILITARY LEADER}

To date, NATO membership is one of Ukraine's main strategic goals, and European principles are the main guidelines for the country's development. The development of modern Ukrainian army cannot be based on Soviet principles of command, as contemporaneousness requires new approaches to military management, building such interaction between military personnel that will be based on the respect, authority, responsibility, and other values of the Ukrainian army.

At the same time, one of the most important conditions for the development of the modern Armed Forces of Ukraine is the development of leadership at all levels of management. One of the criteria for the efficiency of the military leader's management activity is the ability correctly and timely solve the tasks and problems that confront him her in the course of professional activity.

Purpose is to analyse psychological peculiarities of problem solving by military leader in the management activity.

The methodological basis of research are situational theory of leadership, motivation theory, humanistic approach, attribution theory of leadership, transformational leadership, systematic approach in psychology.

The article deals with the attempt of psychological comprehension of leadership problem in the military and social management. The concept «problem» is defined, the typology of problems in the military and professional activity is revealed, the strategies of problems' solving, which are typical for military manager, are presented. The essence of typology of problems' application in the sphere of military practice is revealed.

At the current stage of functioning of the Armed Forces of Ukraine, leadership is not just an effective regulator of managerial activity, but an integral part of the management process itself. Prospects for further research may be problems of implementation and development of leadership in the activities of the Armed Forces of Ukraine.

Key words: leader; problem; management; efficiency; armed forces. 